\title{
Efek Proteksi dari Terapi Oksigen Hiperbarik terhadap Ekspresi Bcl-2 Miometrium Rattus norvegicus Bunting yang Terinfeksi oleh Tachyzoite Toxoplasma gondii
}

\author{
Arif Rahman Nurdianto ${ }^{1 *}$, Aryati ${ }^{2}$, Mohammad Guritno Suryokusumo ${ }^{3}$, Mufasirin ${ }^{4}$ \\ Doctoral Student, Universitas Airlangga; Public Health Office of Sidoarjo, Indonesia; \\ STIKES Anwar Medika Hospital ${ }^{1}$ \\ Professor in Department of Clinical Pathology, Faculty of Medicine, Universitas \\ Airlangga, Indonesia ${ }^{2}$ \\ Aquatic and Hyperbaric Medicine Academie Nationale de Medicine, Paris, France ${ }^{3}$ \\ Department of Parasitology, Faculty of veterinary medicine, Universitas Airlangga, \\ Indonesia ${ }^{4}$ \\ *e-mail: didins99@gmail.com
}

\begin{abstract}
Abstrak
Terapi oksigen hiperbarik (HBOT) dapat meningkatkan hantaran oksigen ke jaringan dan menstimulasi pembentukan $\mathrm{H}_{2} \mathrm{O}_{2}$ sebagai perantara dalam fosforilasi nuclear factor kappa beta (NF-kB) yang sangat penting dalam transkripsi gen anti apoptosis. Penelitian ini bertujuan untuk mencari pengaruh HBOT pada peningkatan ekspresi Bcl-2 di myometrium tikus yang terinfeksi Toxoplasma gondii. Penelitian ini adalah penelitian eksperimental murni dengan randomized control group of post-test only dan menggunakan 37 Rattus norvegicus Sprague Dawley bunting. Tikus secara acak dibagi menjadi empat grup. Grup A merupakan tikus bunting terinfeksi dan mendapatkan HBOT. Grup B merupakan tikus bunting sehat dan tidak terinfeksi tachyzoite serta mendapat HBOT. Grup $\mathrm{C}$ merupakan tikus buting terinfeksi dan tidak mendapatkan HBOT. Grup D merupakan kontrol negatif yakni tikus bunting sehat tanpa mendapatkan HBOT. Tikus yang terinfeksi diberikan $10^{3}$ tachyzoite T.gondii melalui injeksi intraperitoneal. Ekspresi Bcl-2 diperiksa dengan immunohistokimia. Semua data dianalisa dengan menggunakan uji ANOVA melalui aplikasi SPSS 21. Terdapat perbedaan yang signifikan pada ekspresi $\mathrm{Bcl}-2$ antara grup $A$ dan grup $C$ karena $p<\alpha(p<0.017)$. HBOT dapat meningkatkan ekspresi Bcl-2 myometrium tikus terinfeksi maupun tidak terinfeksi dengan pemberian HBOT 2.4 ATA selama $3 \times 30$ menit, 10X terapi yang terbagi menjadi $2 \mathrm{X}$ sehari selama 5 hari.
\end{abstract}

Kata Kunci: Bcl-2, HBOT, Myometrium, Tachyzoite, Toxoplasma gondii

\section{Protective Effect of Hyperbaric Oxygen Therapy to Bcl-2 Expression in the Myometrium of Pregnant Rattus norvegicus Infected by Tachyzoite of Toxoplasma gondii}

\begin{abstract}
Hyperbaric Oxygen Therapy (HBOT) can increase oxygen delivery to tissues and stimulate the formation of $\mathrm{H}_{2} \mathrm{O}_{2}$ as a secondary messenger for phosphorylation of nuclear factor kappa beta (NF-kB) which plays an important role in the transcription of the anti-apoptotic gene. This study aimed to determine the effects of Hyperbaric Oxygen Therapy (HBOT) in enhancing the
\end{abstract}


Efek Proteksi dari Terapi Oksigen Hiperbarik terhadap Ekspresi Bcl-2 Miometrium Rattus...

Arif Rahman Nurdianto, Aryati, Mohammad Guritno Suryokusumo, Mufasirin

expressions of $\mathrm{BCl}-2$ in the myometrium of pregnant rats infected by Toxoplasma gondii. This study was an experimental study with a randomized control group of post-test only and designed by 37 pregnant Rattus norvegicus Sprague Dawley. Randomly, the rats were divided into four groups. Group $A$ is infected pregnant rats that exposed by 10 sessions of HBOT 2.4 ATA in $3 \times 30$ minutes. Group $B$ is non-infected pregnant rats and exposed by 10 sessions of НВОT 2.4 ATA in $3 \times 30$ minutes. Group $C$ is infected pregnant rats without any exposure. Group $D$ is non-infected pregnant rats without any exposure. Each infected pregnant rat was given a $10^{3}$ tachyzoite of T.gondii by intraperitoneal injection. BCl-2 expressions were measured through immunohistochemistry. All data were analyzed using ANOVA test through SPSS 21 program application. There was a significant difference in Bcl-2 expression between Group $A$ and Group $C$ because $p<\alpha(p<0.017)$. HBOT can increase the expression of Bcl-2 from infected and not infected rat myometrium, in the provision of HBOT 2.4 ATA for $3 \times 30$ minutes, twice a day for 5 days.

Keywords: Bcl-2, Hyperbaric Oxygen Therapy, Myometrium, Tachyzoite, Toxoplasma gondii

\section{INTRODUCTION}

Abortion is the end of a pregnancy before the fetus is sufficiently developed to be able to live outside the womb which is before the gestational age of 20 weeks from the date of the first day of last menstruation or fetal weight less than 500 grams. Abortion is still an obstetric problem that has not been widely revealed and is one of the causes of maternal and fetal death (Moscrop, 2013; Jeve and Davies, 2014; Ghasemi et al, 2016).

Bleeding from the birth canal is a symptom in $10-15 \%$ of young pregnancies, half of which end in abortion (Jeve and Davies, 2014; Weiss et al, 2004). Most $(60 \%)$ abortions occur before 12 weeks of gestation and the rest occur in the range of 12-20 weeks (Jeve and Davies, 2014) Increased abortion also occurs in uterine abnormalities, diabetes mellitus, hypothyroidism, cardiac abnormalities, chronic lung disease, increased body mass index, women who smoke, drink alcohol, and others (Ghasemi et al, 2016; Hill et al, 2004).

Factors that are known to play a role in the occurrence of abortion include chromosomal abnormalities, immunological abnormalities, hormonal abnormalities, or maternal infections including $T$. gondii infection. The majority of abortions within the positive group for T. gondii fall in 12 weeks (41\%) followed by $8(15 \%)$ and 10 (12\%) weeks of gestational age (AI-Fertosi and Juma, 2006). There is a likelihood that strong type 1 response induced early during $T$. gondii infection will induce abortion early in pregnancy (Nurdianto et al, 2019a).

Abortion is the most common form of embryonic death caused by early pregnancy failure (Clark et al, 2001). The biomolecular mechanism underlying this 
abortion is not fully understood. There is evidence that shows an increase in uteroplacental apoptosis and in the reproductive organs associated with abnormalities in pregnancy (PrabhuDas et al, 2015). B cell lymphoma 2 (Bcl-2) protein levels in abortion are lower than in normal pregnancies, whereas Caspase-3 protein levels in abortion are higher than in normal pregnancies.

Abortion in pregnancy with $T$. gondii infection is found to be a lower expression of $\mathrm{Bcl}-2$ compared to normal pregnancy. Bcl-2 plays a role in the apoptosis process and abortion through excessive hypoxic mechanisms in pregnancy (Savion et al, 2002). HBOT can reduce the cellular hypoxia by reducing the production of HIF$1 \alpha$ (Choudhury, 2018).

The previous study revealed that HBOT can improve the expressions of Interferon Gamma (IFN $\gamma$ ) and Tumor Necrosis Factor alpha (TNF $\alpha$ ), in the provision of HBOT 2.4 (1 atmosphere absolute/ATA) for $3 \times 30$ minutes, ten times in 5 days and HBOT administration can prevent abortion in pregnant rats infected by tachyzoite $T$. gondii (Nurdianto et al, 2019a). HBOT mechanism in myometrium apoptosis in pregnant rats infected by tachyzoite T.gondii needs to be proven. This study tried to find the influence of HBOT on $\mathrm{Bcl}-2$ expression in the myometrium of pregnant rats infected with tachyzoite T.gondii. The results of this study were expected to explain the mechanism of administration of HBOT in pregnant rats with toxoplasmosis.

\section{MATERIAL AND METHOD}

This study was a study of 37 Sprague Dawley Rattus norvegicus with a post-test only that design randomized control group. This research was performed through ethical clearance No.777_KE from Animal Care and Use Committee (ACUC) Faculty of Veterinary Medicine, Universitas Airlangga. Rats were divided into four groups and given treatment in groups $A, B$ and $C$ while group D is the control group. Group $A$ is infected pregnant rats and exposed by 10 sessions of HBOT 2.4 ATA in $3 \times 30$ minutes. Group B is non-infected pregnant rats and exposed to HBOT. Group C is infected pregnant rats without any exposure. Group $D$ is non infected pregnant rats without any exposure. Each infected pregnant rat was given a $10^{3}$ tachyzoite of $T$. gondii by intraperitoneal injection. Examination of $\mathrm{BCl}-2$ was performed on day- 5 after HBOT (twice a day) with Monoclonal antibody Bcl-2 (10C4) SANTA CRUZ Biotechnology Inc, Dallas, Texas, United States of America. Euthanized or aborted rats had been eliminated, while rats that still survive had been sacrificed to take the myometrium. 
Efek Proteksi dari Terapi Oksigen Hiperbarik terhadap Ekspresi Bcl-2 Miometrium Rattus...

Arif Rahman Nurdianto, Aryati, Mohammad Guritno Suryokusumo, Mufasirin

Bcl-2 Expressions were measured using immunohistochemistry.

\section{Animal Model}

Rats placed at temperature between $20-23^{\circ} \mathrm{C}$. Rats copulated at night and the next day. The female rats were examined for the presence of vaginal plug. If the vaginal plug is positive, it means that the rats have been pregnant for 0.5 day (Clark et al, 2001) The female rat was separated and sent to the Bio-Safety Level 2 Laboratory (BSL2) Faculty of Veterinary Medicine, Universitas Airlangga. Before injecting tachyzoite, the abdomen was touched around the uterus to determine whether the rat is truly pregnant. The first day of the pregnancy was calculated based on the first day of the rats having vaginal plug. Rats which at the time of examination were not found to be pregnant, was left uninfected (Dewi, 2009).

\section{HBOT Protocol}

Rats got HBOT with $100 \%$ oxygen pressure with doses 2.4 ATA, $3 \times 30$ minutes and 5 -minute intervals ( 2 sessions) every day for 10 sessions. The administration of HBOT was carried out in different cages every group (in one chamber). The rats still got ad libitum food and drink when getting HBOT (Rusdiana; 2014).

\section{Immunohistochemistry}

Immunohistochemistry staining used streptavidin and biotin. The uterine tissue in embedding paraffin was cut into $4-5 \mu \mathrm{m}$ thick. Preparations were depinalized in xylol 2 times for 5 minutes in each sample, the respectively entered in absolute ethanol 2 times for 3 minutes, ethanol (95\%) for 2 times each 3 minutes and ethanol (70\%) for 3 minutes, and eventually washed using distilled water. Preparations were dropped with 5 minutes $\mathrm{K}$ proteinase, washed with phosphate buffer saline (PBS) for twice, then dosed with hydrogen peroxidase $\left(\mathrm{H}_{2} \mathrm{O}_{2}\right)(3 \%)$ for 5 minutes and washed using PBS for twice. Each incision was incubated in Bcl-2 antirat monoclonal antibodies for 30 minutes. Subsequently, slice were incubated in secondary antibodies labeled with biotin for 30 minutes, washed using PBS for twice. Then the streptavidin-peroxidase was pressed for 15-30 minutes, washed using PBS for twice and finally put in a solution of diaminobenzidine (DAB) substrate for 5-10 minutes. Counterstain used hematoxylin, incubated for 30 seconds at room temperatures then washed for 3 times using distilled water.

This histopathological examination was intended to determine the expression of myometrial $\mathrm{Bcl}-2$. $\mathrm{Bcl}-2$ expression in each sample was assessed semiquantitatively according to the modified Remmele method (Novak et al, 2007), where the Remmele scale index 
ISSN 1978-2071 (Print); ISSN 2580-5967 (Online) Jurnal IImiah Kedokteran Wijaya Kusuma 9(1): 85-96, Maret 2020

(ImmunoReactive Score/IRS) was the result of multiplication between the percentage of positive immunoreactive cells with color intensity scores on immunoreactive cells. Data for each sample were averaged in IRS value observed in 5 (five) different view fields at $400 x$ magnification. All of these examinations used ordinary light microscopes from the Nikon H600L brand (Nikon Corp., Tokyo, Japan), equipped by a Fi2 DS 300-megapixel digital camera (Nikon Corp., Tokyo, Japan), and Nikkon Image System image processing software (Nikon Corp., Tokyo, Japan). All immunohistochemistry were processed through ImageJ application to count the scale bar. All result from immunohistochemistry expression of $\mathrm{Bcl}-2$ myometrium was checked using One way ANOVA SPSS 21 program application (IBM corp., New York, United States).

\section{RESULTS}

The results of IRS calculation of $\mathrm{Bcl}-2$ expression in myometrial samples that have been treated using immunohistochemical staining shows the following results:

Table 1. Scoring of Bcl-2 Expression

\begin{tabular}{|c|c|}
\hline Group & $\begin{array}{l}\text { Average Expression of } \\
\text { Bcl-2 (IRS) }\end{array}$ \\
\hline$A$ & 5.11 \\
\hline$B$ & 4.23 \\
\hline $\mathrm{C}$ & 2.58 \\
\hline $\mathrm{D}$ & 4.20 \\
\hline
\end{tabular}

myometrium spirals (arrow) expression groups expressed by myosit cells (immunohistochemical staining, 400x magnification; Nikon H600L microscope; 300 megapixels DS Fi2 camera). White marker scale is in $1 \mu \mathrm{m}$
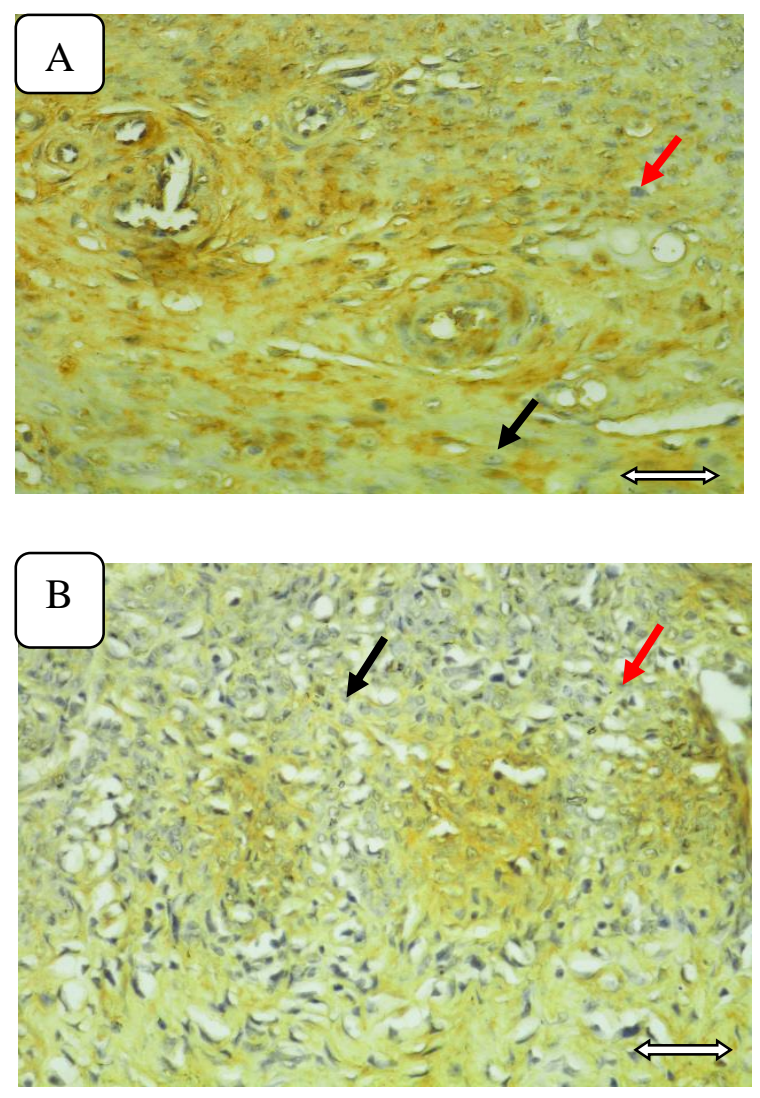

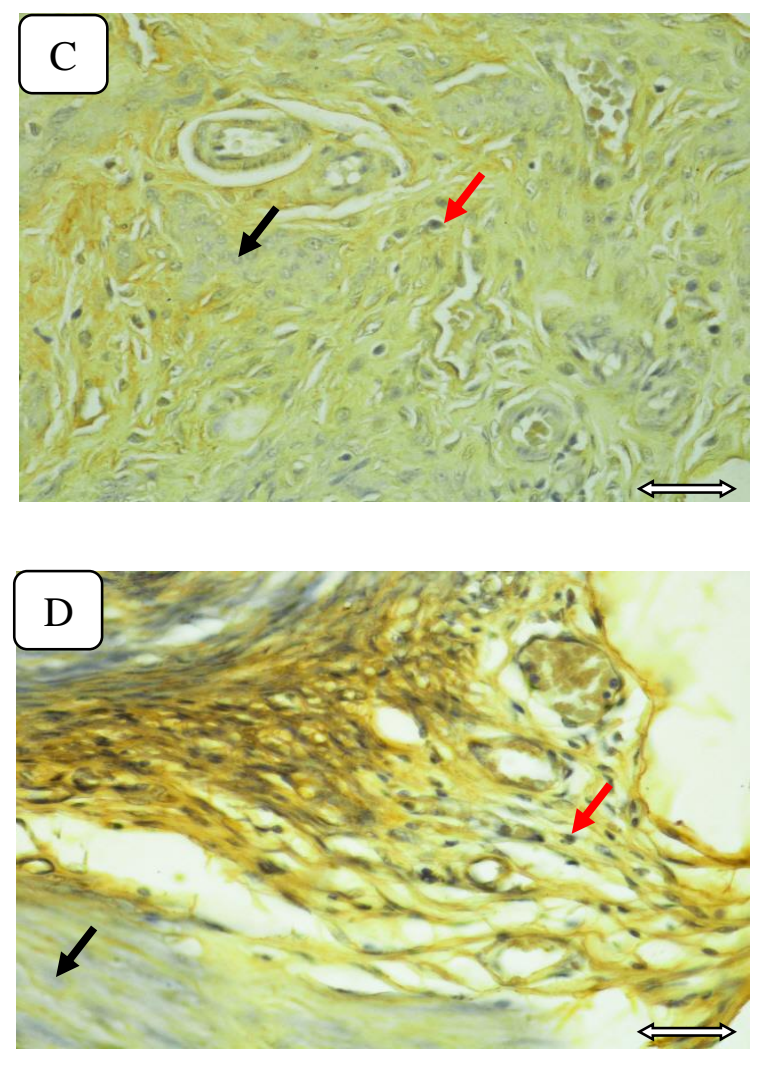

Figure 1. Expression of Bcl-2 Myometrium by Immunohistochemical Staining Red arrows indicate Bcl-2 expression in myocytes cells, while black arrows indicate cells do not express Bcl-2.

Figure $A$ shows that the expression of high Bcl-2 in myometrium layer of pregnant rats infected by tachyzoite which is shown in brown. Figure $B$ shows that the expression of high $\mathrm{Bcl}-2$ in the pregnant myometrium layer of non-infected rats. pregnant rats infected by tachyzoite without HBOT shown in small are of brown color. Figure $D$ above shows that the expression of high $\mathrm{Bcl}-2$ in the myometrium layer of non-infected without any exposure rats, which is shown as Figure $\mathrm{C}$ shows that $\mathrm{Bcl}-2$ expression brown.

decreased in myometrium layer of

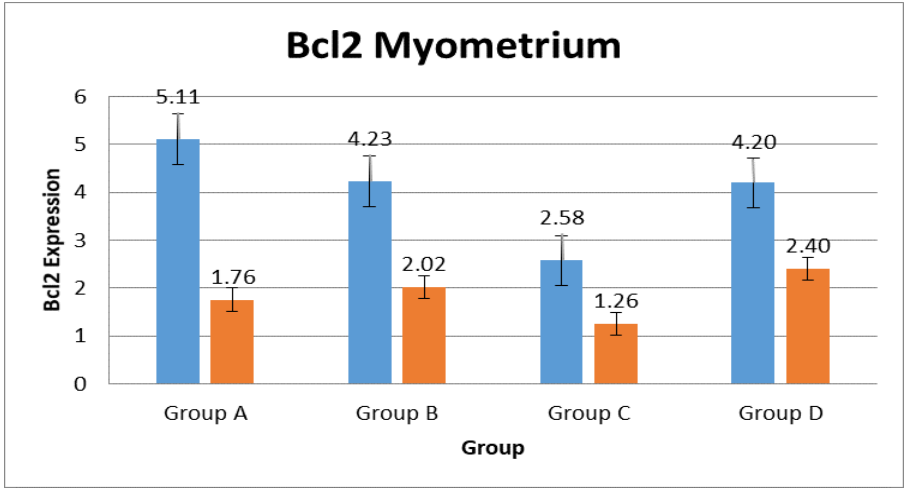

$\mathrm{Bcl}-2$ expression in group

Standard error of the mean

Figure 2. Expression of $\mathrm{Bcl}-2$ in Myometrium among Groups $\mathrm{BCl}-2$ expression in group 
From the Figure 2, we can concluded that the expression of $\mathrm{Bcl}-2$ myometrium in group $A$ and $B$ were high, indicating that administration of HBOT could increase the expression of $\mathrm{Bcl}-2$ from pregnant rats infected with tachyzoite.

Based on the statistical test results ANOVA through SPSS 21 program application, it was found that there was a significant difference between the administration of HBOT between Group A and Group C with $p<0.017$ which means that administration of HBOT in pregnant rats infected by tachyzoite could increase the expression of $\mathrm{Bcl}-2$ in the myometrium.

\section{DISCUSSION}

Pregnancy failure is closely related to an increase in apoptosis, which is controlled by the Bcl-2 family and the caspase cascade (Sun and Zhang, 2017; Bartlett, 2017; Toder et al; 2002). T.gondiiinfected pregnancies abortion is often resulted from apoptosis and abortion due to excessive IFN $\gamma$ production that can down regulate $\mathrm{Bcl}-2$ expression, Fas Ligand (FasL), and protein 53 (p53) (Nurdianto et al, 2019a; Nurdianto et al, 2019b; Sun et al, 2007; Dockrell, 2003; Begum-Haque et al, 2009).

$\mathrm{Bcl}-2$ plays a role as anti-apoptosis and abortion through hypoxia in pregnancy and located in the cytoplasm of the myometrium (Savion et al, 2002; Kelly and Strasser, 2011). A decrease in Bcl-2 protein levels during pregnancy is associated with pregnancy failure (Danihel et al, 2002). Whereas, the administration of HBOT in research rats can increase the amount of dissolved oxygen (Hyperoxia).

$\mathrm{Bcl}-2$ is a proto-oncogene which can inhibit apoptosis including myometrium (Kelly and Strasser, 2011; Opferman and Kothari, 2017) and this protein increased by giving HBOT as in group A (5.11). We can compare it to $\mathrm{Bcl}-2$ levels in group $\mathrm{C}$ (2.58) which was much lower than group A. There was a decrease in $\mathrm{Bcl}-2$ associated with apoptosis and end in abortion in animal studies (Savion et al, 2002), we can see this in group $C$ and it can be concluded that the process of apoptosis in the myometrium of rats infected by tachyzoite could be prevented by HBOT.

The results of immunohistochemical $\mathrm{Bcl}-2$ myometrium found that $\mathrm{Bcl}-2$ levels in group $A, B$, and group $D$ were higher than group $C$. This result explained that in group A, HBOT could prevent myometrium from apoptosis. These results are supported by previous research data which state that administration of HBOT can increase anti-apoptotic proteins ( $\mathrm{BCl}-2$ and $\mathrm{Bcl}-\mathrm{xl})$ and reduce the expression of genes that trigger apoptosis such as c-for, c-jun, Bax and Caspase 3 (Liu et al, 2006; 
Efek Proteksi dari Terapi Oksigen Hiperbarik terhadap Ekspresi Bcl-2 Miometrium Rattus...

Arif Rahman Nurdianto, Aryati, Mohammad Guritno Suryokusumo, Mufasirin

Vlodavsky et al, 2006; Xu et al, 2012;

Barbosa et al, 2015; Torchinsky and Toder, 2004). The HBOT can reduce apoptosis by suppressing mitochondrial-mediated apoptotic pathways by triggering $\mathrm{Bcl}-2$ expression and maintaining intact mitochondria involving three components, including FasL, Fas, and Caspase-3 (Palzur et al, 2008; De Falco et al, 2004; Huppertz et al, 2006).

The process of apoptosis in the placenta and myometrium is associated with abnormal pregnancies (Jerzak and Bischof, 2002). Research in mice shows that the process of apoptosis causes cell death in the placenta and the occurrence of miscarriage (Jerzak and Bischof, 2002; Savion et al, 2002). In this study, we can see that tachyzoite infection in pregnant rats without HBOT therapy has decreased the expression of $\mathrm{Bcl}-2$ myometrium in group $C(2,58)$ while in the group $D, B c l-2$ levels are (4.2). This explains that tachyzoite posed a risk of apoptosis in the myometrium which has the potential to cause fetal abortion.

Excessive apoptosis in the uterus may result in pregnancy failure and most likely to occur if $\mathrm{Bcl}-2$ levels also decrease dramatically as in group $C$. The possibility of abortion in group $\mathrm{C}$ was greater than group $A, B$, and $D$ which has a higher $\mathrm{Bcl}-2$ level (Toder et al, 2002; Jerzak and Bischof, 2002; Savion et al, 2002)

\section{CONCLUSION}

HBOT can improve the expressions of $\mathrm{Bcl}-2$ in myometrium, in the provision of HBOT 2.4 ATA for $3 \times 30$ minutes, ten times in 5 days.

\section{ACKNOWLEDGMENTS}

Thanks to the study group of Toxoplasma gondii Faculty of Veterinary Medicine of Universitas Airlangga who was willing to provide tachyzoite sample for this research. Thank you also to the Department of Hyperbaric, Faculty of Medicine, Universitas Hang Tuah Surabaya on the permission to use Hyperbaric Chamber. Thanks to the Regent of Sidoarjo and the Head of Public Health Office Sidoarjo for the permission to conduct the study. Thank you also for my Professor in Universitas Airlangga who was willing to advise me in my dissertation.

\section{DISCLOSURE}

The author reports no conflicts of interest in this work.

\section{REFERENCES}

Al-Fertosi RB and Juma ASM, 2006. Possible Cellular Expression of IFNY in a Woman With Abortion 
Infected Toxoplasma Gondii. Medical Journal of Islamic World Academy of Sciences. 16(3): 121134.

Barbosa BF, Lopes-Maria JB, Gomes AO, Angeloni MB, Castro AS et al, 2015. IL10, TGF Beta1, and IFN Gamma Modulate Intracellular Signaling Pathways and Cytokine Production to Control Toxoplasma gondii Infection in BeWo Trophoblast Cells. Biology Reproduction. 92(3): 82.

Bartlett Z, 2017. Apoptosis in Embryonic Development. Embryo Project Encyclopedia. ISSN: 1940-5030 http://embryo.asu.edu/handle/1 0776/11565.

Begum-Haque S, Haque A, Kasper LH, 2009. Apoptosis in Toxoplasma gondii Activated T cells: the role of IFNY in Enhanced Alteration of $\mathrm{Bcl}-2$ Expression and Mitochondrial Membrane Potential. Microb Pathog. 2009 November; 47(5): 281-288.

Clark DA, Coulam CB, Daya S, Chaouat G, 2001. Unexplained Sporadic and Recurrent Miscarriage in The New Millenium: A Critical Analysis of Immune Mechanisms and Treatments. Hum Reprod update. 7(5): 501-511.
Choudhury R, 2018. Hypoxia and hyperbaric oxygen therapy: a review. Int J Gem Med. 11: 431442.

Danihel L, Gomolcak P, Korbel M, Pruzinec, J, Vojtaššak J et al, 2002. Expression of Proliferation and Apoptotic Markers in Human placenta During Pregnancy. Acta Histochem. 104(4): 335-338.

De Falco M, Fedele V, Cobellis L, Mastrogiacomo A, Leone $\mathrm{S}$ et al, 2004. Immunohistochemical Distribution of Proteins Belonging to The Receptor-Mediated and The Mitochondrial Apoptotic Pathways in Human Placenta During Gestation. Cell Tissue Res. 318(3): 599-608.

Dewi BDN, 2009. Efek Terapi Kombinasi Metformin-Oksigen Hyperbaric Pada Pasien Diabetes Mellitus Tipe 2: Peningkatan Kadar Endothelial Nitric Oxidesynthase (eNOS) dan Penurunan Kadar Glukosa Darah. Tesis. Surabaya. Universitas Airlangga.

Dockrell DH, 2003. The Multiple Roles of Fas Ligand in The Pathogenesis of Infectious Diseases. Clin Microbiol Infect. 9(8): 766-779. 
Efek Proteksi dari Terapi Oksigen Hiperbarik terhadap Ekspresi Bcl-2 Miometrium Rattus...

Arif Rahman Nurdianto, Aryati, Mohammad Guritno Suryokusumo, Mufasirin

Ghasemi FS, Rasti S, Piroozmand A, Bandehpour M, Kazemi B et al 2016. Toxoplasmosis-

Associated Abortion, and Stillbirth in Tehran, Iran. J Matern Fetal Neonatal Med. 29(2): 248251.

Hill JA. 2004. Recurrent Pregnancy Loss. in: Creasy RK, Resnik R, editor. Maternal-Fetal Medicine Principle and Practice. $5^{\text {th }}$ edition, Philadelphia: Saunders: 579-601.

Huppertz B, Kadyrov M, Kingdom JC, 2006. Apoptosis and Its Role in The Trophoblast. Am J Obstet Gynecol. 195(1): 29-39.

Jerzak $M$ and Bischof $P, 2002$. Apoptosis in The First-Trimester Human Placenta: The Role in Maintaining Immune Privilege at The Maternal-Foetal Interface and in The Trophoblast Remodeling. Eur J Obstet Gynecol Reprod Biol. 100(2): 138-142.

Jeve YB and Davies W, 2014. EvidenceBased Management of Recurrent Miscarriages. J Hum Reprod Sci. 7(3): 159-169.

Kelly PN and Strasser A, 2011. The Role of $\mathrm{Bcl}-2$ and Its Pro-Survival Relatives in Tumorigenesis and Cancer Therapy. Cell Death Differ. 18(9): 1414-1424.
Liu Z, Jiao QF, You C, Che YJ, Su FZ, 2006. Effect of Hyperbaric Oxygen on Cytochrome C, Bcl-2 and Bax Expression after Experimental Traumatic Brain Injury in Rats. Chin J Traumatol. 9(3): 168-174.

Moscrop A, 2013. 'Miscarriage or abortion?' Understanding the Medical Language of Pregnancy Loss in Britain; A Historical Perspective. Med Humanit. 39(2): 98-104.

Novak M, Madej JA, Dziegeil P, 2007. Intensity of Cox 2 expression in Cell of Soft Tissue Fibrosarcomas in Dogs as Related to Grade of Tumour Malignancy. Bull Vet inst Pulawy. 51, 275-279.

Nurdianto AR, Aryati, Suryokusumo MG, Mufasirin, 2019a. Effect of Hyperbaric Oxygen Therapy to IFNY and TNFa Expression in Pregnant Rattus norvegicus Infected with Tachyzoite of Toxoplasma gondii. Bali Medical Journal; 8(1): 94-100.

Nurdianto AR, Aryati, Suryokusumo MG, Mufasirin, 2019b. Downregulates of ICAM1 expression in Myometrium from pregnant Rattus norvegicus infected with Tachyzoite of Toxoplasma gondii with Hyperbaric Oxygen Therapy. 
Hang Tuah Medical Journal; 17(1): 77-83

Opferman J and Kothari A, 2017. AntiApoptotic BCL-2 Family Members in Development. Cell Death and Differentiation. 25(1): 37-45.

Palzur E, Zaaroor M, Vlodavsky E, Milman F, Soustiel JF, 2008. Neuroprotective Effect of Hyperbaric Oxygen Therapy in Brain Injury is Mediated by Preservation of Mitochondrial Membrane Properties. Brain Res. 1221:126-133.

PrabhuDas M, Bonney E, Caron K, Dey S, Erlebacher A et al, 2015. Immune Mechanisms at the MaternalFetal Interface: Perspectives and Challenges. Nat Immunol. 16(4): 328-334.

Rusdiana D, 2014. Efek Oksigen Hyperbaric Terhadap Peningkatan Ekspresi Akt pada Rattus norvegicus dengan Diabetes Mellitus. Tesis. Surabaya. Universitas Airlangga.

Savion S, Lepsky E, Orenstein H, Carp H, Shepshelovich J et al, 2002. Apoptosis in the Uterus of Mice with Pregnancy Loss. Am J Reprod Immunol. 47(2): 118-127.

Sun QH, Peng JP, Xia HF, Yang Y. 2007. IFN$\checkmark$ Promotes Apoptosis of the Uterus and Placenta in Pregnant
Rat and Human Cytotrophoblast Cells. J Interferon Cytokine Res. 27(7): 567-578.

Sun $Q$ and Zhang XL. 2017. Research on Apoptotic Signaling Pathways of A Recurrent Spontaneous Abortion Caused By Dysfunction of Trophoblast Infiltration. Eur Rev Med Pharmacol. 21(3 Suppl) : 1219.

Toder V, Carp H, Fein A, Torchinsky A, 2002. The Role of Pro and AntiApoptotic Molecular Interactions in Embryonic Maldevelopment. Am J Reprod Immunol. 48(4): 235244.

Torchinsky A and Toder V, 2004. To Die or Not to Die: The Function of the Transcription Factor NF-kB in Embryos Exposed to Stress. Am J Reprod Immunol. 51(2): 138-143.

Vlodavsky E, Palzur E, Soustiel JF, 2006. Hyperbaric Oxygen Therapy Reduces Neuroinflammation and Expression of Matrix Metalloproteinase-9 in The Rat Model of Traumatic Brain Injury. Neuropathol Appl Neurobiol. 32(1): 40-50.

Weiss JL, Malone FD, Vidaver J, Ball RH, Nyberg DA et al, 2004. Threatened Abortion: A Risk Factor Poor Pregnancy Outcome, 
Efek Proteksi dari Terapi Oksigen Hiperbarik terhadap Ekspresi Bcl-2 Miometrium Rattus...

Arif Rahman Nurdianto, Aryati, Mohammad Guritno Suryokusumo, Mufasirin
A Population-Based Screening
Expression in Rabbits with Blast
Study. Am J Obstet Gynecol.
Brain Injury Following Early 190(3): 745-750.
Hyperbaric Oxygen Therapy.
Xu S, Liu J, Zhang Y, Wang C, Wang J et al,
Neural Regen Res. 7(17): 1318-
2012. Apoptosis-Related Protein
1324. 